\title{
In-vivo analgesic activity of ethanol leaf extract of Sphenocentrum Jollyanum in albino mice.
}

\author{
Emmanuel Uka ${ }^{\mathrm{a}}$, Jessie Idongesit Ndem ${ }^{\mathrm{a}}$, Patrick Amagwu Iberi ${ }^{\mathrm{b}}$, Esther Oluwasola Aluko ${ }^{\mathrm{c}}$ \\ emmanueluka@uniuyo.edu.ng
}

${ }^{a}$ Department of Biochemistry, Faculty of Basic Medical Sciences, University of Uyo, Uyo, Nigeria.
${ }^{b}$ Department of Pharmacognosy and Natural medicine, Faculty of Pharmacy, University of Uyo
${ }^{\mathrm{c}}$ Department of Human Physiology, Faculty of Basic Medical Sciences, University of Uyo, Nigeria.

\begin{abstract}
This study assessed the in-vivo analgesic activity of ethanol leaf extract of Sphenocentrum jollyanum in albino mice using analgesic models such as acetic acid-induced abdominal writhing, formalin-induced paw licking and thermally-induced pain in mice. Acetylsalicylic acid (ASA) was used as the reference drugs for the acid-induced abdominal writhing and formalin-induced paw licking while Dexamethasone was used as standard drug for thermally-induced pain. A total of seventy-five matured Swiss Albino mice of both sexes weighing between 15 - 25 $\mathrm{g}$ (divided into three groups of 25 mice each for the 3 different studies) were used for this study. They were randomly divided into 5 groups of five mice each. Group I served as the normal control and received $10 \mathrm{~mL} / \mathrm{kg}$ body weight (bw) distilled water. Group II (Standard control), received standard drugs- Acetylsalicylic acid (ASA) or Dexamethasone. Groups III, IV and V received 474.34, 948.68 and $1423.03 \mathrm{mg} / \mathrm{kg}$ bw ethanol leaf extract of $S$. jollyanum respectively. All administration was done intraperitoneally. The animals were fed normal rat pellet and had water ad libitum. The results showed a significant $(\mathrm{p}<0.05)$ dose dependent reduction in the acetic acid-induced abdominal writhing and formalin-induced paw licking at all doses (Groups III -V) compared with acetylsalicylic acid standard drug Group II. In the acetic acid-induced writhing and formalin paw licking models, the extract had the highest writhing and paw licking effects of $37.40 \pm 0.68$ and $28.60 \pm 0.60$ at the highest dose of $1423.03 \mathrm{mg} / \mathrm{kg}$ respectively. Similarly, the extract caused a dose-dependent increase in percentage inhibition of abdominal writhing and paw licking effects at total timing of $105 \mathrm{mins}$ with the highest dose of $1423.03 \mathrm{mg} / \mathrm{kg}$ respectively. Additionally, the extract (groups III-V) and standard drug (II) demonstrated a dose-dependent $(\mathrm{p}<0.05)$ increase in PRT compared with control group I, with the standard drug dexamethasone (group II) having the highest effect. Sphenocentrum Jollyanum leaves extract also showed significant increase in PRT from 135 to 190\% compared to control group I. The result obtained from this study suggests that the extract of Sphenocentrum Jollyanum leaf may be an effective analgesic agent that may act by the inhibition of prostaglandin synthesis or via peripheral mechanism of pain inhibition.
\end{abstract}

Keywords: Sphenocentrum jollyanum; pain; analgesic; abdominal writhing; paw licking. 


\section{Introduction}

Pain is a warning mechanism that protects an organism by making it withdraw from harmful stimuli that is primarily associated with injury or may be a threat of injury. It is also a complex experience in which cognitive, affective and behavioural features, representing psychological conditions are affected [1]. The International Association for the Study of Pain (IASP) defines pain as an unpleasant sensory and emotional experience associated with actual or potential tissue damage, or described in terms of such damage. Pain can be acute or chronic and can develop into chronic pain syndrome, if left untreated [2]. Different reasons such as harmful heat, stretch, electrical flow, necrosis, inflammation, laceration and spasm can bring about pain [3]. A wide variety of degenerative diseases such as rheumatoid arthritis, polymyalgia rheumatica, as well as heart, asthma, cancer and inflammatory bowel diseases have been reported to be associated with inflammatory processes and pains [1]. Pain therefore, is an indication of several illnesses and it is predicted that about $80-100 \%$ of the population will experience pain at some point in their life [4]). Although pain is mainly considered as a defense mechanism which is created when tissue is damaged and caused a person to show reaction with removal of pain stimulant [5], about 22\% of primary care patients suffer from pain which persists for more than six months and in some cases, the percentage rises to $50 \%$ and is related to significant impairment of social functioning and quality of life [6].

The global burden of morbidity due to pain has been reported to be huge and due to its frequent occurrences, it is a health problem that reduce the quality of life and possesses socioeconomic effect both on the patients and their families [7]. Treatment modalities for pains include physical therapies such as heat or cold packs, massage, hydrotherapy and exercise; psychological therapies such as cognitive behavioural therapy, relaxation techniques and meditation; mind and body techniques such as acupuncture; occupational therapy and pain-relieving medicines such as analgesics, antidepressant, anticonvulsant [8]. Two types of over-the-counter (OTC) pain medications; acetaminophen (Panadol) and nonsteroidal anti-inflammatory drug (NSAIDs) such as aspirin, naproxen and ibuprofen have also been used to treat pains [9]. Gastrointestinal irritation, bronchospasm, fluid retention, and extension of bleeding has been reported as some adverse effects associated with several over the counter anti-inflammatory and analgesic drugs [10].

Over the years, good health has been the greatest challenge to mankind globally. Long term pains impose undesirable mental effects. There is a report on several ways to decrease or eliminate pain [11]. Medicinal plants have been suggested to present natural, effective substances for prevention or treatment of pain-related conditions [12]. Natural products from plants, animals and minerals has also been reported to have contributed in the development of new drugs and for treating human diseases [13]. The use of plants for food and medicinal purposes in the management of various disease conditions has increased due to the unavailability of modern health facilities, relative availability of medicinal herbs, poverty and recent relations that they possess active compounds that may be responsible for different biological and pharmacological actions with no adverse effects [14]. One of such plant is Sphenocentrum jollyanum used commonly in south eastern part of Nigeria for the treatment of pains. It is an undergrowth shrub plant that thrives in deep shade and commonly found in the tropical forest of West Africa. Sphenocentrum jollyanum belongs to the family Menispermaceae and is locally called Oji-enyi, Ajo or Akerejupon 
and Ibong Isong by the Igbos, Yorubas and the Ibibios respectively [15]. The leaves are wedge in shape and is about $5-12 \mathrm{~cm}$ wide and smooth on both sides and can grow up to about $20 \mathrm{~cm}$ long with a small arrowed apex [16]. The leaves have been reported to be rich in phytoconstituents such as alkaloids, saponins, tannins, phlobatannins, flavonoids and cardiac glycosides, with the $\mathrm{LD}_{50}$ of $4743.42 \mathrm{mg} / \mathrm{kg}$ body weight [17]. Different parts of the plants such as the leaves, stem and roots have been reported to possess ethnomedicinal values and has effect in central nervous system (CNS) diseases such as psychiatric disorders, inflammation and pains [18]. It is also used in the treatment of blood pressure, breast tumor, irregular menstrual cycle, and diabetes mellitus [16;19;20;21;22]. Sphenocentrum jollyanum have also been found to be potent against polio type-2 viruses [23]. The plant extract is popular in chronic wound dressing, feverish conditions, cough and as an aphrodisiac [24,16,25]. Earlier studies have shown that the ethanolic extract of Sphenocentrum jollyanum root increased libido and enhanced sexual behaviour in male mice [26].

Studies have also shown that the metabolic stem bark extract of the plant possesses significant hepatoprotective and antioxidant properties against carbon tetrachloride-induced stress in rats [27]. Petroleum ether and methanol extracts of $S$. Jollyanum leaves has been reported in previous studies to possess significant in-vitro analgesic and antipyretic properties [28]. This study aims at assessing for analgesic activity of ethanolic leaf extract of Sphenocentrum jollyanum in-vivo in experimental mice.

\section{Materials and Methods}

\subsection{Chemical and instrument}

Acetylsalicylic acid (ASA) and dexamethasone were purchased from Sigma Aldrich (St. Louis, MO, USA) were used as the standard drugs. Acetic acid was obtained from Merck (Darmstadt, Germany) while formalin was obtained from Nihon Shiyaku Industries (Japan). Ethanol was obtained from JHD, China. Scientific hotplate (Thomas autoregulated temperature model, USA) and Ohaus weighing scale (Ohaus Corporation, USA, model: Scout pro-SPU 202) were from the Pharmacognosy Laboratory, University of Uyo, Uyo. All other chemicals and reagents used were of analytical grade and acquired from local firms

\subsection{Sample Collection and Preparation of extract}

Fresh leaves of Sphenocentrum jollyanum (S. Jollyanum) commonly were collected from Aka in Ibiono Ibom Local Government Area of Akwa Ibom State, Nigeria. They were identified and authenticated by a taxonomist in the Department of Pharmacognosy and Natural Medicine, University of Uyo, Akwa Ibom State with a voucher no NUUH:040/15 and the specimen deposited at the herbarium. The leaves were washed with clean water to remove accumulated dirt's and air-dried for two weeks at room temperature. Eight hundred and thirty-three point seven grammes $(833.7 \mathrm{~g})$ of the powdered sample was macerated in 1.5 litre of $60 \%$ ethanol for 72 hours and intermittently shaken to allow the solvent to solubilized the active ingredients. The mixture was filtered using muslin cloth and thereafter filtered with Whatman No. 1 filter paper to obtain a yellowish brown coloured filtrate. The filtrate was concentrated in a water bath at $45^{\circ} \mathrm{C}$ to obtain a paste-like gel extract that was further dried in a desiccator between 28 to $33{ }^{\circ} \mathrm{C}$ to completely eliminate all the solvent to yield $188.5 \mathrm{~g}$ of crude extract.

\subsection{Experimental Animals and Design}


Seventy-five matured Swiss Albino mice of both sexes weighing between $15-25 \mathrm{~g}$ were procured from the Animal House, Department of Pharmacognosy and Toxicology, Faculty of Pharmacy, University of Uyo, Uyo, were used for this study. The mice were kept in stainless steel cages under laboratory conditions, fed with commercial pelleted feed (Ladokun Feeds, Nigeria Ltd) and were allowed distilled water ad libitum. The animals were acclimatized for two weeks before the commencement of administration. The mice were randomly divided into 5 groups of five mice each. The care and use of the animals were in compliance with standard protocols of the National Institute of Health guidelines for the care and use of Laboratory Animals [29].

The treatment groups were as follows:

Group I: Normal control that received $10 \mathrm{~mL} / \mathrm{kg}$ body weight distilled water.

Group II: Standard control that received standard drug; Acetylsalicylic acid (ASA) and Dexamethasone respectively Group III: Received $474.34 \mathrm{mg} / \mathrm{kg}$ bw ethanol leaf extract of $S$. jollyanum

Group IV: Received $948.68 \mathrm{mg} / \mathrm{kg}$ bw ethanol leaf extract of $S$. jollyanum

Group V: Received $1423.03 \mathrm{mg} / \mathrm{kg}$ bw ethanol leaf extract of $S$. jollyanum

\subsection{Determination of the Analgesic activity of Sphenocentrum jollyanum}

The following methods were adopted in this study to assess for analgesic property of Sphenocentrum jollyanum;

\subsubsection{Acetic acid-induced abdominal writhing}

Analgesic activity of ethanol leaf extracts of Sphenocentrum jollyanum against acetic acid-induced writhing was performed according to the procedure by [30;31;32]. Twenty-five Swiss albino mice (15-22g) of both sexes were randomly divided into 5 groups of 5 mice each and fasted for 24 hours but still had water ad libitum. Control group I received $10 \mathrm{~mL} / \mathrm{kg}$ distilled water, group II received $50 \mathrm{mg} / \mathrm{kg}$ acetylsalicylic acid (ASA) which serves as a standard drug while groups III, IV and V were given $474.34 \mathrm{mg} / \mathrm{kg}, 948.68 \mathrm{mg} / \mathrm{kg}$ and $1423.03 \mathrm{mg} / \mathrm{kg}$ doses of ethanol leaf extract of Sphenocentrum jollyanum respectively. All administrations were done intraperitoneally.

After 30 minutes of administration of the extract and the standard drug, $0.2 \mathrm{~mL}$ of acetic acid (3\%) solution was injected intraperitoneally. The number of writhing movements characterized by contraction of abdominal muscles followed by opening back feet or body stretching in the animals were observed and counted immediately and recorded at intervals of 5 minutes for 30 minutes according to method described by [33]. The degree of antinociception (analgesia) was expressed as the reduction of the number of abdominal constrictions between control animals and mice pretreated with extracts.

\subsubsection{Percentage inhibition of acetic acid-induced abdominal writhing}

The percentage inhibition of the writhing response was calculated from the equation described by [34] and presented in Figure 1.

Percentage $(\%)$ writhing inhibition $=\mathrm{W}_{\frac{\mathrm{c}}{\mathrm{Wc}} \mathrm{W}} \times 100$

where $\mathrm{Wc}$ is the mean number of writhes in the control and $\mathrm{W}$ is the mean number of writhes in the extract group.

\subsubsection{Formalin-induced paw licking in mice}

Formalin test was carried out according to methods by [35;36;37]. Twenty-five adult Swiss albino mice (15-25g) of both sexes were randomized into 5 groups of 5 mice per group. They were fasted for 24 hours but still had water ad 
libitum. Group I received $10 \mathrm{~mL} / \mathrm{kg}$ distilled water orally (negative control), group II received $100 \mathrm{mg} / \mathrm{kg}$ acetylsalicylic acid (ASA) while groups III, IV and V were pretreated with $474.34 \mathrm{mg} / \mathrm{kg}, 948.68 \mathrm{mg} / \mathrm{kg}$ and $1423.03 \mathrm{mg} / \mathrm{kg}$ doses of ethanol leaf extract of Sphenocentrum jollyanum. All administrations were done intraperitoneally.

Thirty minutes after treatment of the extract and drug, $0.02 \mathrm{~mL}$ of $2.5 \%$ formalin solution was injected subcutaneously under the surface of the right hind paw of each mouse. The time durations of licking/ biting of the formalin - injected paw by the mice were observed and recorded for 30 minutes. The time interval between the paw licks was observed and recorded as the index of pain.

\subsubsection{Percentage inhibition of formalin-induced paw licking in mice}

The percentage inhibition of the paw licking for the acute phase (i.e. 0-5 mins) and chronic (5-30 mins) of the analgesic activity of formalin injection, representing the neurogenic and inflammatory pain response were calculated using the formula:

$$
\% \text { inhibition }=\frac{(\mathrm{Do}-\mathrm{Dt})}{\mathrm{Do}} \times 100
$$

Where Do was the average number of paw licks of the control group, while Dt was the number of paw licks of the treated group. The results are presented in Figure 2

\subsubsection{Thermally-induced pain in mice}

The methods described by [38,39] was used to determine the effect of thermally-induced pain in this study. Twentyfive (25) mature albino mice (15-20g) of both sexes were randomly divided into 5 groups of 5 mice per group were used for the experiment. The mice were fasted for 24 hours but still received water ad libitum before treatment. Group I received $10 \mathrm{~mL} / \mathrm{kg}$ of distilled water and served as the negative control. Groups II received $4 \mathrm{mg} / \mathrm{kg}$ body weight dexamethasone (standard drug) while groups III, IV and V were pretreated with $474.34 \mathrm{mg} / \mathrm{kg}, 948.68 \mathrm{mg} / \mathrm{kg}$ and $1423.03 \mathrm{mg} / \mathrm{kg}$ of ethanol leaf extract of Sphenocentrum jollyanum. All administration was done intraperitoneally.

In this experiment, the hot plate was maintained at $45 \pm 1^{\circ} \mathrm{C}$ and a glass beaker of $50 \mathrm{~cm}$ diameter was placed on the heated surface. The mice were dropped into the beaker and were immediately removed as soon as responses like kicking its hind foot and jumping about, licking and shaking of foot, raising one or the other of the hind foot and holding the foot tightly to its body were noticed as described by [40]. The time it took for the animal to elicit the reflexive pain behaviour was taken as the pain reaction time (PRT) and recorded for each of the animals after the administration of the treatments. A maximum reaction time of 30 seconds was observed to prevent any injury to the tissues of the paws of the mice as described by [41]. Prolongation of the reaction time in the drug treated animals compared to the control indicates analgesic effect.

\subsubsection{Percentage inhibition of thermally-induced pain in mice}

The percentage increase or decrease in reaction time of thermally-induced pain in mice (as index of analgesia) at each time was calculated from the equation described by [42] and presented in Figure 3.

$\%$ inhibition $=\underline{(\mathrm{Rt})}-1 \times 100$

$\mathrm{Rc}$ 
where $\mathrm{Rt}=$ reaction time in treated group; $\mathrm{Rc}=$ reaction time in control group.

\subsection{Statistical Analysis}

All results are expressed as mean \pm standard error of the mean (SEM) and were analyzed using one-way analysis of variance (ANOVA). Post hoc analysis (comparison across groups) was carried out using the least significant difference (LSD) incorporated into the IBM SPSS software version 20 . The values of $\mathrm{p}<0.05$ were considered to be statistically significant 


\subsection{Results and Discussion}

\subsection{Acetic acid-induced abdominal writhing}

Table 1. Effect of ethanol leaf extract of Sphenocentrum Jollyanum on acetic acid-induced writhing in mice.

\begin{tabular}{|c|c|c|c|c|c|c|c|c|c|}
\hline Group & Treatment & Dosage & 5 mins & 10 mins & $\begin{array}{l}\text { Writhing Time Int } \\
15 \text { mins }\end{array}$ & $\begin{array}{l}\text { tervals } \\
20 \text { mins }\end{array}$ & 25 mins & 30 mins & $\begin{array}{l}105 \text { mins } \\
\text { (Total time) }\end{array}$ \\
\hline $\begin{array}{l}D \\
(1\end{array}$ & $\begin{array}{l}\text { Distilled Water } \\
(\mathrm{mL} / \mathrm{kg})\end{array}$ & 10 & $22.00 \pm 0.95$ & $16.20 \pm 0.66$ & $12.60 \pm 0.51$ & $7.00 \pm 0.32$ & $5.80 \pm 0.66$ & $4.00 \pm 0.32$ & $65.40 \pm 2.1$ \\
\hline $\begin{array}{l}\text { A } \\
(1\end{array}$ & $\begin{array}{l}\text { ASA } \\
(\mathrm{mg} / \mathrm{kg} \text { bw) }\end{array}$ & 50 & $14.00 \pm 0.95^{\mathrm{a}}$ & $11.00 \pm 0.63^{\mathrm{a}}$ & $5.40 \pm 0.51^{\mathrm{a}}$ & $3.00 \pm 0.32^{\mathrm{a}}$ & $1.80 \pm 0.49^{\mathrm{a}}$ & $0.40 \pm 0.24^{\mathrm{a}}$ & $35.60 \pm 2.23^{\mathrm{a}}$ \\
\hline III & $\begin{array}{l}\text { S. Jollyanum } \\
\text { (mg/kg bw) }\end{array}$ & 474.34 & $17.40 \pm 0.51^{\mathrm{a}, \mathrm{b}}$ & $15.20 \pm 0.49^{b}$ & $11.20 \pm 0.73^{b}$ & $5.40 \pm 0.24^{\mathrm{a}, \mathrm{b}}$ & $3.00 \pm 0.32^{\mathrm{a}}$ & $2.80 \pm 0.20 \stackrel{\mathrm{a}, \mathrm{b}}{\mathrm{m}}$ & $55.00 \pm 1.41^{\mathrm{a}, \mathrm{b}}$ \\
\hline IV & $\begin{array}{l}\text { S. Jollyanum } \\
\text { (mg/kg bw) }\end{array}$ & 948.68 & $16.00 \pm 0.55^{\mathrm{a}}$ & $12.40 \pm 0.51^{a, c}$ & $7.00 \pm 0.32^{a, b, c}$ & $4.00 \pm 0.32 \underset{\mathrm{a}, \mathrm{b}, \mathrm{c}}{\mathrm{m}}$ & $2.80 \pm 0.66^{\mathrm{a}}$ & $1.20 \pm 0.20 \mathrm{a}, \mathrm{b}, \mathrm{c}$ & $43.40 \pm 1.5 \mathrm{a}, \mathrm{b}, \mathrm{c}$ \\
\hline V & $\begin{array}{l}\text { S. Jollyanum } \\
\text { (mg/kg bw) }\end{array}$ & 1423.03 & $15.00 \pm 0.32 \mathrm{a}, \mathrm{c}$ & $12.20 \pm 0.37^{a, c}$ & $3.20 \pm 0.49 a, b, c, d$ & $3.20 \pm 0.20 \mathrm{a}, \mathrm{c}$ & $3.00 \pm 0.32^{\mathrm{a}}$ & $0.80 \pm 0.20 \mathrm{a}, \mathrm{c}$ & $37.40 \pm 0.68 \mathrm{a,c}$ \\
\hline
\end{tabular}

Results presented as mean \pm S.E.M; $n=5 ; \mathrm{p}<0.05$ is considered significant. a $=$ significant when all test groups is compared with control group $1, \mathrm{~b}=$ significant when group 2 is compared with control. $\mathrm{c}=$ significant when groups $4 \& 5$ are compared with $3 . \mathrm{d}=$ significant when groups $4 \mathrm{vs} 5$ are compared. ASA: acetylsalicylic acid. bxw $=$ body weight 


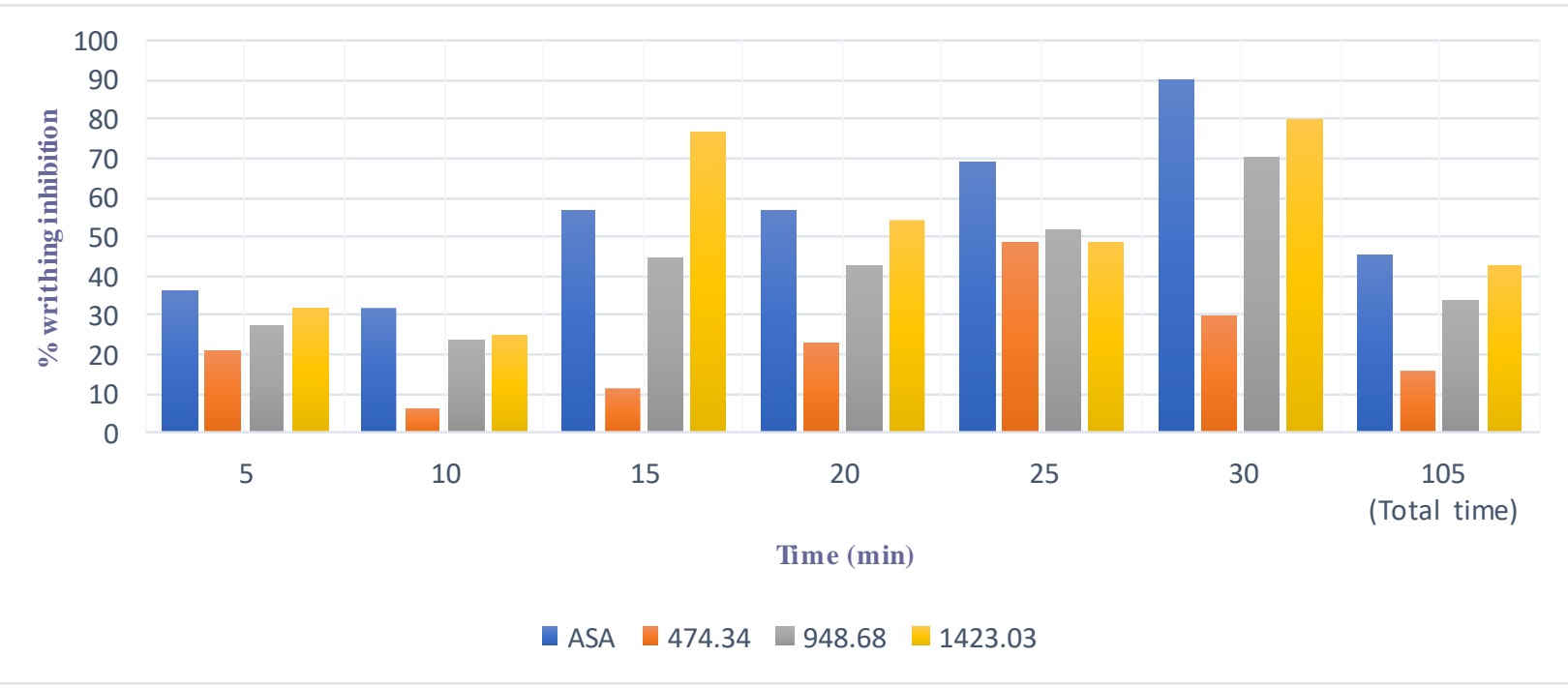

Figure 1: Percentage inhibition of ethanol extract of Sphenocentrum Jollyanum on acetic acid-induced writhing in mice.

The in-vivo analgesic activity of ethanol extract of Sphenocentrum jollyanum leaves using feasible analgesic models such as acetic acid-induced abdominal writhing, formalin-induced paw licking and thermally-induced pain in albino Wistar mice was investigated in this study.

Acetic acid-induced writhing reflex is a visceral pain model nociception which is highly useful for screening analgesic drugs and several chemicals such as phenyl paraquinine, bradykinin and acetic acid that could induce a pain reaction characterized as writhing response reflex in laboratory animals [43]. Various pain mediators such as kinins, acetylcholine, substance $\mathrm{P}$, calcitonin-gene-related peptide and prostaglandins (PG) are also known to initiate writhing reflexes in animals through direct activation of chemo sensitive nociceptors that detect noxious stimuli [44]. Acetic acid-induced writhing model produces pain sensation in animals by triggering an inflammatory response and such pain stimulus leads to the release of arachidonic acid from tissue [45]. Writhing of the abdomen, turning of the trunk (twist) and extension of the hind limbs is considered as some writhing reaction to chemically induced pain in animals [46]. The level of analgesia in acetic acid-induced models is indicated by the percentage reduction in the number of abdominal constrictions [47]. In this study, administration of different doses of ethanol extract of Sphenocentrum Jollyanum leaves (474.34, 948.68 and $1423.03 \mathrm{mg} / \mathrm{kg}$ ) resulted in a dose-dependent significant reduction in the abdominal writhing responses in mice after acetic acid injection compared to the control (Table 1). When all the test groups were compared with control group I, there was significant $(\mathrm{p}<0.05)$ decreased abdominal constrictions initiated by the intraperitoneal administration of acetic acid-induced writhing after 105 mins that was highest in acetylsalicylic acid standard drug group II. The highest percentage inhibition (42.8\%) was observed at the highest dose and was comparable with acetylsalicylic acid standard drug (45.6\%) (Figure 1). This effect may be mediated through peripheral pain mechanism or through suppression of prostaglandin pathway. It has been documented that agents that decreases the number of writhing demonstrate their analgesic effect by the inhibition of prostaglandin synthesis or via peripheral mechanism of pain inhibition [48]. Analgesia activity through peripheral analgesic that inhibits prostaglandin biosynthesis by acting on visceral receptors sensitive to acetic acid has also been reported [49]. 


\subsection{Formalin-induced paw licking}

\subsection{Formalin-induced paw licking}

Table 2 Effect of ethanol leaf extract of Sphenocentrum Jollyanum on formalin induced paw licking in mice.

\begin{tabular}{|c|c|c|c|c|c|c|c|c|c|}
\hline \multirow[b]{2}{*}{ Group } & \multirow[b]{2}{*}{ Treatment } & \multirow[b]{2}{*}{ Dosage } & \multirow[b]{2}{*}{5 mins } & \multicolumn{4}{|c|}{ Paw Licking Time Intervals } & \multirow[b]{2}{*}{$30 \mathrm{mins}$} & \multirow[b]{2}{*}{$\begin{array}{l}105 \text { mins } \\
\text { (Total time) }\end{array}$} \\
\hline & & & & 10 mins & 15 mins & $20 \mathrm{mins}$ & 25 mins & & \\
\hline I. & $\begin{array}{l}\text { Distilled Water } \\
(\mathrm{mL} / \mathrm{kg})\end{array}$ & 10 & $20.20 \pm 1.11$ & $15.20 \pm 0.49$ & $6.20 \pm 0.49$ & $2.80 \pm 0.200$ & $9.00 \pm 4.58$ & $2.20 \pm 0.49$ & $45.00 \pm 0.95$ \\
\hline II & $\begin{array}{l}\text { ASA } \\
(\mathrm{mg} / \mathrm{kg} \text { bw) }\end{array}$ & 100 & $12.80 \pm 0.80^{\mathrm{a}}$ & $4.20 \pm 1.02^{\mathrm{a}}$ & $2.80 \pm 0.66^{\mathrm{a}}$ & $1.80 \pm 0.37$ & $5.00 \pm 1.15$ & $0.60 \pm 0.24^{\mathrm{a}}$ & $24.00 \pm 2.97^{\mathrm{a}}$ \\
\hline III & $\begin{array}{l}\text { S. Jollyanum } \\
\text { (mg/kg bw) }\end{array}$ & 474.34 & $14.80 \pm 0.66^{\mathrm{a}}$ & $13.00 \pm 0.32 \mathrm{a,b}$ & $6.00 \pm 0.32^{b}$ & $2.40 \pm 0.40$ & $2.20 \pm 0.20$ & $2.00 \pm 0.32^{b}$ & $40.80 \pm 0.49^{b}$ \\
\hline IV & $\begin{array}{l}\text { S. Jollyanum } \\
\text { (mg/kg bw) }\end{array}$ & 948.68 & $14.00 \pm 0.63^{\mathrm{a}}$ & $8.80 \pm 0.66^{a, b, c}$ & $5.80 \pm 0.20^{b}$ & $2.40 \pm 0.80$ & $1.80 \pm 0.37$ & $1.80 \pm 0.20^{b}$ & $35.00 \pm 0.84 \mathrm{a}, \mathrm{b}, \mathrm{c}$ \\
\hline V & $\begin{array}{l}\text { S. Jollyanum } \\
(\mathrm{mg} / \mathrm{kg} \mathrm{bw})\end{array}$ & 1423.03 & $13.00 \pm 0.32^{\mathrm{a}}$ & $6.00 \pm 0.84 \mathrm{a,c,d}$ & $5.20 \pm 0.20^{b}$ & $2.20 \pm 0.20$ & $1.20 \pm 0.20^{\mathrm{a}}$ & $1.00 \pm 0.32^{\mathrm{a}, \mathrm{c}}$ & $28.60 \pm 0.60 \mathrm{a}, \mathrm{b}, \mathrm{c}$ \\
\hline
\end{tabular}

Results presented as mean \pm S.E.M; $\mathrm{n}=5 ; \mathrm{p}<0.05$ is considered significant. $\mathrm{a}=$ significant when all test groups is compared with control group $1, \mathrm{~b}=$ significant when group 2 is compared with control. $\mathrm{c}=$ significant when groups $4 \& 5$ are compared with $3 . \mathrm{d}=$ significant when groups $4 \mathrm{vs} 5$ are compared. ASA: acetylsalicylic acid. bux $=$ body weight. 


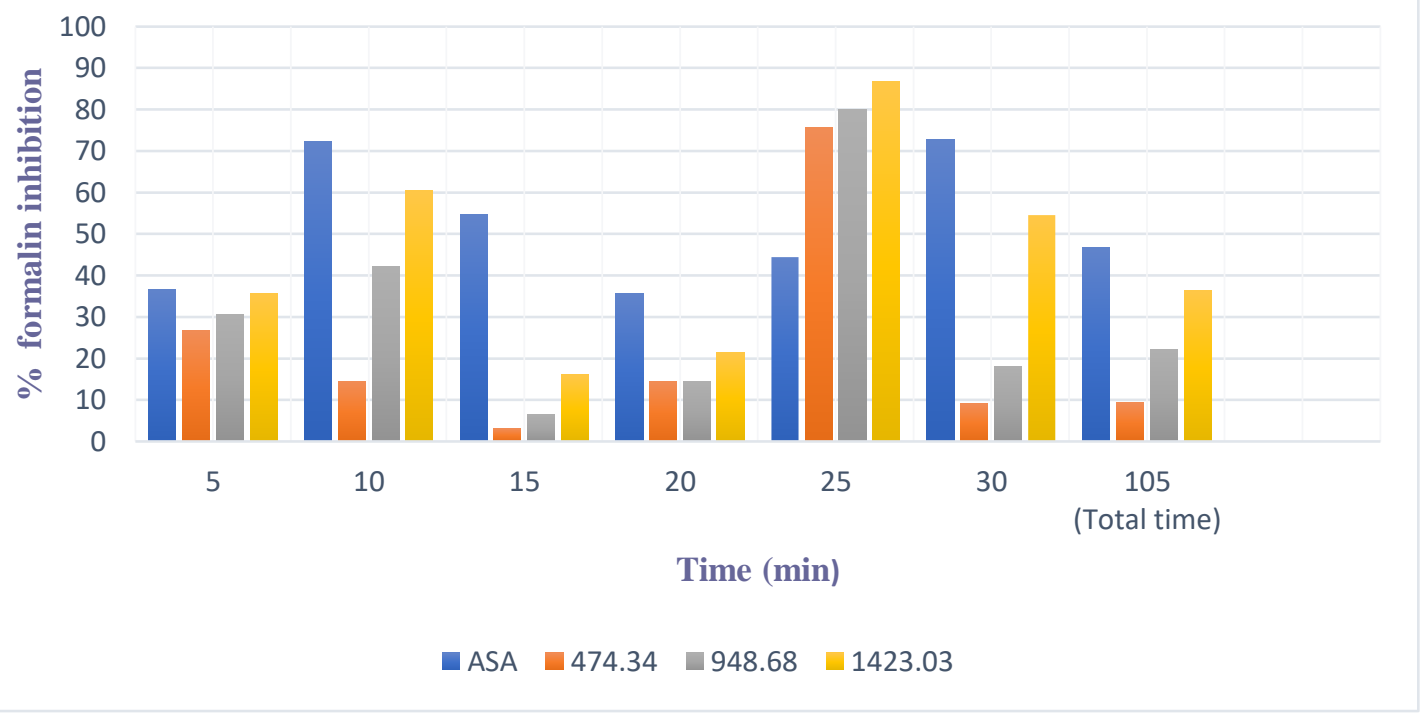

Figure 2: Percentage inhibition of ethanol extract of Sphenocentrum Jollyanum on formalin-induced paw licking in mice.

The formalin-induced paw licking model is another method devised to evaluate the analgesic effect of new drugs [50]. Formalin induced possesses two distinct phases reflecting the different types of pain. During the first phase (0-5 min), there is a direct chemical stimulation of the nociceptors (neuropathic or noninflammatory pain) from chemical stimulation that provoked the release of bradykinin and substance P, whereas the second phase $(15-30 \mathrm{~min})$ shows the involvement of inflammatory mediators such as histamine, 5- hydroxytryptamine (5-HT), prostaglandins and bradykinin [51]. The injection of formalin in mice has been reported to cause behavioural response such as paw licking, which is a biphasic response [52;53]. The first phase of formalin-induced hind paw licking is centrally mediated [54], while the late phase of formalininduced hind paw licking is peripherally mediated. The extractability of any agent to inhibit both phases of formalin-induced paw licking has been suggested to be as a result of the inhibition of pain mediators such as bradykinins, substance $\mathrm{P}$, histamine and prostaglandins. This is consistent with the action of centrally acting analgesics while peripherally acting analgesics act only during the second phase of the model [55]. Administration of different doses of the Sphenocentrum Jollyanum extract also resulted in a dose-dependent significant $(\mathrm{p}<0.05)$ reduction in the formalin-induced paw licking in mice compared with the control group I after 105 mins, that was highest in acetylsalicylic acid standard drug group II (Table 2). Equally, Sphenocentrum Jollyanum leaf extract caused a dose-dependent increase in percentage inhibition of paw licking, increasing from 9.3 to $36.4 \%$ at total timing compared with standard drug (46.7\%) (Figure II). The reduction of the time of paw licking in both phases of measurement indicates that the ethanol extract of Sphenocentrum Jollyanum leaf may have the potential to exert anti-nociceptive effects on both inflammatory and non-inflammatory pain. This significant effect of Sphenocentrum Jollyanum leaf extract may be probably 
mediated via both neurogenic and inflammatory mechanisms. The analgesic effect may be enhanced by its rich presence of phytochemicals such as flavonoids, alkaloids, tannins, and saponins [17]. These phytochemicals may act individually or synergistically. Phytochemicals constituents have been documented to possess significant analgesic and antipyretic activities [56].

\subsection{Thermally-induced pain}

Table 3 Effect of ethanol leaf extract of Sphenocentrum Jollyanum on thermally-induced pain in mice

\begin{tabular}{llll}
\hline \multicolumn{1}{c}{ Group } & \multicolumn{1}{c}{ Treatment } & Dosage & Reaction Time (seconds) \\
\hline I. & $\begin{array}{l}\text { Distilled Water } \\
(\mathrm{mL} / \mathrm{kg})\end{array}$ & 10 & $16.00 \pm 1.41$ \\
II & $\begin{array}{l}\text { Dexamethasone } \\
(\mathrm{mg} / \mathrm{kg} \mathrm{bw})\end{array}$ & 4 & $48.40 \pm 3.98^{\mathrm{a}}$ \\
III & $\begin{array}{l}\text { S. Jollyanum } \\
(\mathrm{mg} / \mathrm{kg} \text { bw) }\end{array}$ & 474.34 & $37.60 \pm 4.66^{\mathrm{a}, \mathrm{b}}$ \\
IV & $\begin{array}{l}\text { S. Jollyanum } \\
(\mathrm{mg} / \mathrm{kg} \mathrm{bw})\end{array}$ & 948.68 & $41.40 \pm 3.14^{\mathrm{a}}$ \\
$\mathrm{V}$ & $\begin{array}{l}\text { S. Jollyanum } \\
(\mathrm{mg} / \mathrm{kg} \text { bw) }\end{array}$ & 1423.03 & $46.40 \pm 2.48^{\mathrm{a}}$
\end{tabular}

Results presented as mean \pm S.E.M; $\mathrm{n}=5 ; \mathrm{p}<0.05$ is considered significant. $\mathrm{a}=$ significant when all test groups is compared with control group $1, \mathrm{~b}=$ significant when group 2 is compared with control. $\mathrm{c}=$ significant when groups $4 \& 5$ are compared with 3 . $\mathrm{d}=$ significant when groups 4vs5. ASA: acetylsalicylic acid. bw =body weight.

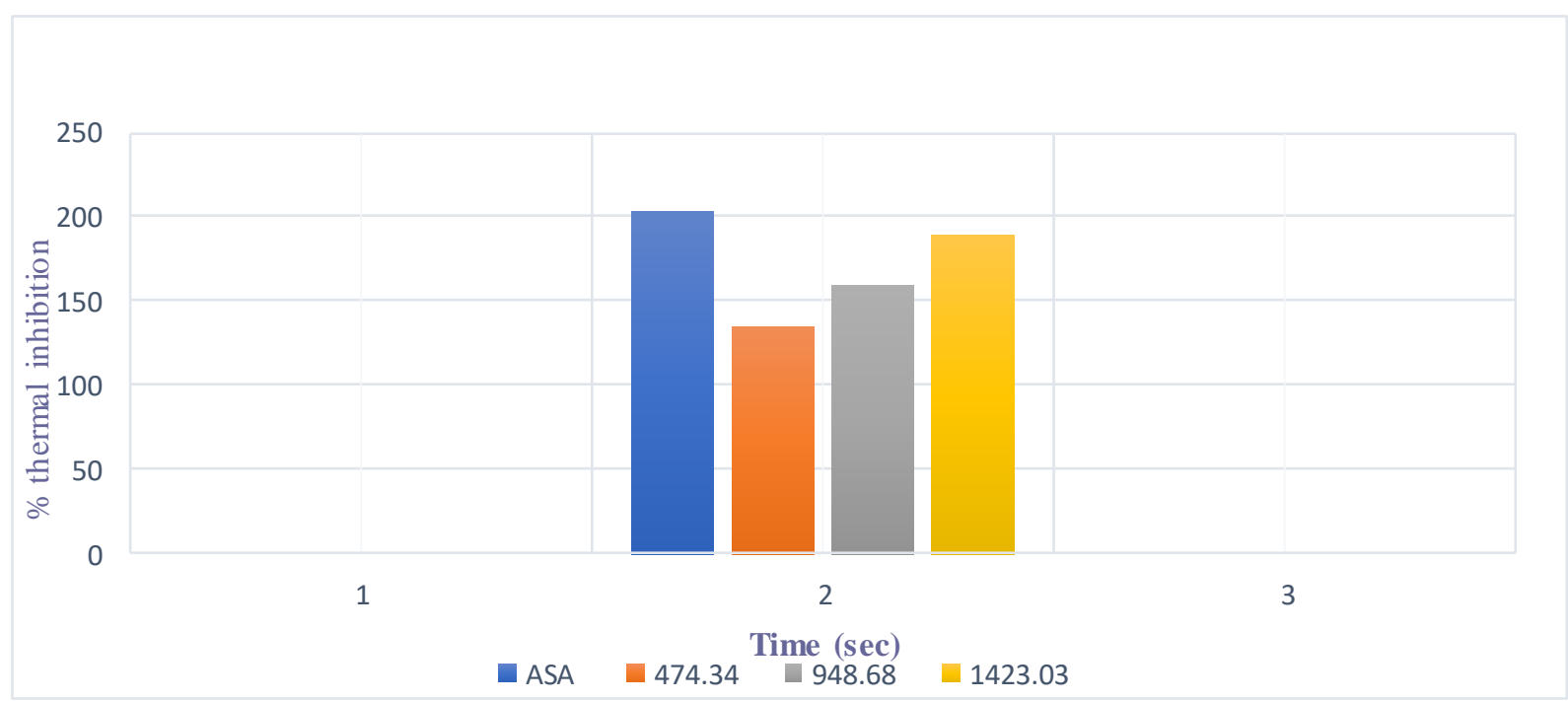

Figure 3: Percentage inhibition of ethanol extract of Sphenocentrum Jollyanum on thermally-induced pain in mice. 
Sphenocentrum Jollyanum leaf extract showed a significant $(\mathrm{p}<0.05)$ increase in the prolongation of pain reaction time (PRT) or latency to thermally induced pain in a dose-dependent manner when compared with control and the highest percentage inhibition was observed with highest dose when compared to other doses (Table 3). This suggest that the leaves of Sphenocentrum Jollyanum have prolonged latency period of analgesic activity. Centrally-acting antinociceptive drugs has been reported to increase the pain threshold of animals towards heat and pressure [57]. This centrally acting analgesics exert their analgesia by inhibiting cyclooxygenase pathway of arachidonate metabolism, which produces prostaglandins. These prostaglandins have a variety of effects on blood vessels, nerve endings and cells involved in inflammation [58]. The leaf extract of Sphenocentrum Jollyanum may exert this effect by inhibiting this pathway. This maybe further made possible because of its rich phytochemical constituents. A number of alkaloids, saponins, tannins, phlobatannins, flavonoids and cardiac glycosides among others isolated from medicinal plants have been reported to possess significant analgesic activity [59]

\section{Conclusion}

The result obtained from this study suggest that the leaf extract of Sphenocentrum jollyanum may possess significant analgesic activity. The analgesic potential of the extract may be due to the rich phytochemical constituent of the leaf extract such as alkaloids, saponins, tannins, phlobatannins, flavonoids and cardiac glycosides. However, further investigations are required to isolate and characterize the bioactive compounds of extract of Sphenocentrum jollyanum leaf and its mechanism of action ascertained.

\section{Acknowledgments}

This research was not supported by any organization or funding body. However, the authors contributed collectively to carry out the research.

\section{REFERENCES}

1. Raj, P. P. Taxonomy and classification of pain. In: Kreitler S, Beltrutti D, Lamberto A, Niv D, editors. The handbook of chronic pain. Nova Biomedical Books, New York. Pp. 2007; 41-56.

2. International Association for the Study of Pain (IASP). IASP taxonomy. Retrieved 2017; March4, 2018, from http://www.iasp pain.org/Education.

3. Rafieian-Kopaei M., Ghobadi, S., Nasri, H. The protective effect of garlic extract on diabetic nephropathy. Journal of Isfahan Medical School; 2013;31(248):1267-1269.

4. Jain, K. N., Kulkarni, K. S., Singh, A. Modulation of NSAID-induced antinociceptive and anti-inflammatory effects by alpha2-adrenoceptor agonists with gastroprotective effects. Life Sciences; 2002; (70): 2857-2869, 10. DOI: 1016/S0024-3205(02)01549-7. 
5. Baradaran, A., Madihi, Y., Merrikhi, A., Rafieian-Kopaei, M., Nasri, H. Serum lipoprotein (a) in diabetic patients with various renal function not yet on dialysis. Pak J Med Sci; 2013; 29(Suppl 1): 354357.

6. Huguet, A., Miró, J. The severity of chronic pediatric pain: an epidemiological study. J Pain; 2008; 9(3): 226-236.

7. Goldberg, D. S, McGee, S. J. Pain as a global public health priority. BMC Public Health; 2011; 11:770. doi:10.1186/1471-2458-11-770.

8. Better Health Channel. Pain and pain management-adults. 2020; https: www. Betterhealth.vic.gov.au.

9. Rang, H.P., Dale, M.M., Ritter, J.M., Moore, P. K. Pharmacology, 2003; 5th edition. London: Churchill Livingstone.

10. Osadebe, P. O., Okoye, F. B. C. Anti-inflammatory effects of crude methanolic extract and fractions of Alchorneacordifolia leaves. Journal of Ethnopharmacology; 2003; 89:19-24. DOI: 10.1016/S0378-8741(03)00195-8.

11. Nasri, H., Rafieian-Kopaei, M. Tubular kidney protection by antioxidants. Iran J Public Health; 2013; 42(10): 1194-1196.

12. Efferth, T., Kuete, V. Cameroonian medicinal plants: pharmacology and derived natural products. Frontiers in Pharmacology; 2010; 1:123.

13. Firenzuoli, F., Gori, L. Herbal medicine today: clinical and research issues. Evid Based Complement Alternat Med. 2007; 4(Suppl 1):37-40. doi: 10.1093/ecam/nem096.

14. Tiwari, A.K., Mehta, R. Medicinal plants used by traditional healers in Jashpur district of Chhattisgarh India. Life Sci. Leafl. 2013; 1, 31-41.

15. Nia, R., Paper, D.H., Essien, E.E., Iyadi, K.C., Bassey, A.I.L., Antai, A.B., Franz, G. Evaluation of the Anti-oxidant and Anti-Angiogenic effects of Sphenocentrum jollyanum Pierre. African Journal of Biomedical Research; 2004; (7) 129 - 132.

16. Iwu, M.M. Handbook of African Medicinal Plants; CRC Press: Boca Raton, FL, USA; 1993; p. 239.

17. Uka, E., Oboso, E. E., Akaninyene, O. E., Imoh, E. J. Phytochemicals, acute toxicity and in-vitro antioxidant activity of ethanol extract of Sphenocentrum jollyanum leaves. Journal of Drugs and Pharmaceutical Science; 2020; 4(2),10-20.

18. Oke, J., Hamburger, M. Screening of some Nigerian Medicinal Plants for Antioxidant Activity Using 2,2-diphenyl-picryl-hydrazyl radical. African Journal of Biomedical Research, 2002; 5: 77-79.

19. Odugbemi, T. Medicinal Plants by Species Names: Outlines and Pictures of Medicinal Plants from Nigeria; Lagos University Press: Ojo, Lagos State, Nigeria.2006 
20. Oliver-Bever, B. Medicinal Plants in Tropical West Africa; Cambridge University Press: Cambridge, UK.1986.

21. Kayode, J., Ige, O.E., Adetogo, T.A., Igbakin, A.P. Conservation and Bio derversity in Ondo State, Nigeria. Survey of plant barks used in native pharmaceutical extraction in Akoko region. EthnoBot. Leafl. 2009; 13, 665-667.

22. Fasola, T.R., Egunyomi, A. Bark extraction and uses of some medicinal plants. Niger. J. Biotechnol.2002; 15, 23-36.

23. Moody, J. O., Roberts, V. A., Connolly, J. D and Houghton, P. J. Anti- inflammatory activities of the methanol extracts and an isolated furanoditerpene constituent of Sphenocentrum jollyanum Pierre (Menispermaceae). J Ethnopharmacol. 2006; 104: 87-91.

24. Burkill, H. M. The Useful Plants of West Tropical Africa; Royal Botanical Gardens, UK, 1985; 1: 1-7.

25. Dalziel, J. M. The useful plants of west tropical Africa. Crown Agents. London. 1985

26. Owiredu, W.A., Amidu, N., Amissah, F., Woode, E. The effects of ethanol extract of root of Sphenocentrum jollyanum Pierre on sexual behavior and hormonal levels in rodents. J. Sci. Technol; 2007; 27, 9-21.

27. Olorunnisola, O.S., Akintola, A.A., Afolayan, A.J. Hepatoprotective and antioxidant effect of Sphenocentrum jollyanum (Menispermaceae) stem bark extract against CCl4-induced oxidative stress in rats. Afr. J. Pharm. Pharmacol; 2011; (5): 1241-1246.

28. Muko, K.N., Ohiri, P.C., Ezugwu, C.O. Antipyretic and analgesic activities of Sphenocentrum jollyanum. Niger. J. Nat. Prod. Med.; 1998; 2:52-53.

29. National Institute of Health. Public health service policy on human care and use of laboratory animals. OLAW.nih.gov.2015

30. Santos, A. R., Cechinel, F. V., Niero, R., Viana, A. M., Moreno, F. N., Campos, M. M., Yunes, R. A, Calixto, J. B. Analgesic effects of callus culture from selected species of Phyllanthus. J. Pharm. Pharmacol. 1994; 46; 755 - 759.

31. Correa, C. R., Kyle, D. J., Chakravarty, S., Calixto, J. B. Antinociceptive profile or the pseudo peptide b2 bradykinin receptors antagonist NPC 18688 in mice. Br J Pharmacol; 1996; 117:552-556.

32. Nwafor, P. A., Nwajiobi, N., Uko, I. E., Obot, J. S. Analgesic and anti-inflammatory activities of an ethanol extract of Smilax krausiana leaf in mice. Afr J Biomed Res; 2010; 13:141-148.

33. Alibabaei, Z., Pilehvarian, A., Shirani, M., Kheiri, S., Taji, F., Asgari, A. Effect of Euphorbia helioscopia on acetic acid-induced abdominal constrictions in Balb/c mice. J Shahrekord Univ Med Sci; 2010; 11(4): 9-14. 
34. Rashid, M. H., Sujit, B., Mohammed, A., Jamilur, R.B. Phytochemical screening and analgesic, antibacterial and cytotoxic activity evaluation of ethanol extract of Pithcellobiumdulce (roxb.) Benth leaf. Asian J Pharm Clin Res, 2015; (2) 451-457.

35. Hunskaar, S., Hole, K. The formalin test in mice: Dissociation between inflammatory and noninflammatory pain. Pain; 1987;30: 103-114.

36. Correa, C. R., Calixto, J. B. Evidence of participation of $\beta 1$ and $\beta 2$ Kinin receptors informationinduced nociceptive response in mouse. British Journal of Pharmacology; 1993; 110: 193-198.

37. Nwafor, P. A., Okwuasaba, F. K. Anti-conceptive and anti-inflammatory effects of methanolic extract to Asparagus pubescens root in rodents. Journal of Ethnopharmacology; 2003; 84: 125-129.

38. Vaz, Z. R., Cechinel, V., Yunes, R. A., Calixto, J. B. Antinociceptive action of 2-(4-bromobenzoyl)-3methyl-4-6-dimethoxy benzofuran, a novel xanthoxyline derivative of chemical and thermal models of nociception in mice. J Pharm Exp Ther; 1996; 278:304-312.

39. Okokon, J. E., Nwafor, P. A. Anti-inflammatory, analgesic and antipyretic activities of ethanolic root extract of Croton zambesicus. Pak J Pharmaceut Sci; 2010; 23:383-390.

40. Mishra, D., Ghosh, G., Kumar, P. S., Panda, P. K. An experimental study of analgesic activity of selective COX-2 inhibitor with conventional NSAIDs, Asian Journal of Pharmaceutical and Clinical Research; 2011; (4)1,78-81.

41. Rafieian-Kopaei, M., Sewell, R. D. E. Involvement of the serotonin system in SSRI-induced antinociception. Med J Islam Repub Iran; 1999; 12(4): 359-364.

42. Sopan, B.P., Kshitij, R.P., Anil, C.N., Sudhir, A., Ananda, P.R.B. Evaluation of Analgesic activity of Hibiscus tiliaceus Linn Wood. World J Pharma Pharmaceu Sci.2012; 1(1):290-7.

43. Raquibul, S. M., Hossain, M. M, Aktar, R., Jamila, M., Mazumder, M. E. H., Alam, M. A. Analgesic Activity of the Different Fractions of the Aerial Parts of Commenila benghalensis Linn. International Journal of Pharmacology; 2010; 6(1):63-67.

44. Matsuda, M., Huh, Y., Ji, R.R. Roles of inflammation, neurogenic inflammation, and neuroinflammation in pain. J. Anesth. 2019; (33):131-139.

45. Lorke, D. A new approach to practical acute toxicity. Archives of Toxicology; 1983; (53):275-289.

46. Vogel, H.G. Drug Discovery and Evaluation, Pharmacological Assays. 2nd ed. Springer Verlag: Berlin, Heidelberg.2002.

47. Machioro, M., Blank, M.F.A., Moura, R. H. V., Antioniolli, A. R. Antinociceptive Activity of the Aqueous Extract of Erythrina velutina leaves. Fitoterapia; 2005; (76):637-642. 
48. Ferdous, M., Rouf, R., Shilpi, J.A, Uddin, S.J. The anti-nociceptive activity of the ethanolic extract of Ficus racemosa (Lin) Oriental Pharm Exp Med; 2008; 8:93-96.

49. Sheikh, B. Y., Zihad, S. N. K., Sifat, N., Uddin, S. J., Shilpi, J. A., Hamdi, O. A. Comparative study of neuropharmacological, analgesic properties and phenolic profile of Ajwah, Safawy and Sukkari cultivars of date palm (Phoenix dactylifera). Orient. Pharm. Exp. Med. 2016; (16):175-183.

50. Hunskaar, S., Fasmer, O.B, Hole, K. Formalin test in mice, a useful technique for evaluating mild analgesics. Journal of Neuroscience Methods; 1985; 14(1):69- 76.

51. Segawa, S., Takata, Y., Kaneda, H., Watari, J. Effects of a Hop Water Extract on the Compound 48/80Stimulated Vascular Permeability in ICR Mice and Histamine Release from OVA-Sensitized BALB/c Mice. Biosci. Biotechnol. Biochem. 2007; (71):1577-1581.

52. Miranda, H.F., Sierralta, F., Prieto, J.C. Synergism between NSAIDs in the orofacial formalin test in mice. Pharmacol Biochem Behav: 2009; (92): 314-18.

53. Raboisson, P., Dallel, R. The orofacial formalin tests. Neurosci Biobehav Rev: 2004; (28):219-26.

54. Berken, T., Ostunes, L., Lermioglu, F., Ozer, A. Anti-inflammatory, analgesic, and antipyretic effects of an aqueous extract of Erythraea Centaurium. Planta Med: 1991; (57):34-37.

55. Le Bars, D., Gozariu, M., Cadden, S.W. (2001). Animal models of nociception. Pharmacol. Rev. 2001; (53):597-652.

56. Muko, K.N., Ohiri, P.C., Ezugwu, C.O. Antipyretic and analgesic activities of Sphenocentrum jollyanum. Niger. J. Nat. Prod. Med; 1998; (2):52-53.

57. Fan, S.H., Ali, N. A., Basri, D.F. Evaluation of analgesic activity of the methanol extract from the galls of Quercus infectoria (olivier) in rats. Evid. Based Complement. Alternat. Med. 2014; 976764.

58. Bertram, G. K. Basic and Clinical Pharmacology. 8ed. McGraw-Hill Companies. New York. Pp 2001;596-597.

59. Sengupta, R., Sheorey, S. D., and Hinge, M. A. (2012). "Analgesic and anti-inflammatory plants: an updated review," International Journal of Pharmaceutical Sciences Review and Research, 2012;12 (2):114-119. 